\title{
Penambahan Level Bumbu Rendang yang Berbeda pada Pembuatan Telur Asin Terhadap Uji Organoleptik
}

\author{
Ayun Andi Rahmah ${ }^{1}$, Warnoto ${ }^{1}$ dan Endang Sulistyowati ${ }^{{ }^{*}}$ \\ ${ }^{1}$ Jurusan Peternakan, Fakultas Pertanian, Universitas Bengkulu, Jalan W. R Supratman, Kandang Limun, Bengkulu, \\ 38371A \\ *Penulis korespondensi: ensulistyowati@yahoo.com
}

Artikel ini diterima (received): 31 Maret 2020; dinyatakan disetujui (accepted): 25 November 2020; terbit (published): 27 November 2020. Artikel ini dipublikasi secara daring pada https://ejournal.unib.ac.id/index.php/buletin_pt/index

\begin{abstract}
Abstrak
Penelitian ini bertujuan untuk mengevaluasi penambahan level bumbu rendang yang berbeda pada pembuatan telur asin terhadap uji organoleptik. Penelitian telah dilaksanakan pada bulan Maret sampai April 2017 bertempat di Laboratorium Jurusan Peternakan Fakultas Pertanian Universitas Bengkulu. Penelitian ini menggunakan 80 butir telur itik yang disusun berdasarkan Rancangan Acak Lengkap (RAL) dan dibahas secara deskriptif. Terdiri dari 4 perlakuan dan 4 ulangan setiap ulangan menggunakan 5 butir telur itik, perlakuan tersebut adalah : P0 : Adonan $+0 \%$ bumbu rendang (kontrol), P1 : Adonan $+25 \%$ bumbu rendang, P2 : Adonan $+50 \%$ bumbu rendang dan P3 : Adonan $+75 \%$ bumbu rendang. Variabel yang diamati pada penelitian ini adalah uji organoleptik warna putih telur, warna kuning telur, aroma, rasa, tekstur dan kesukaan. Hasil penelitian menunjukkan bahwa skor warna putih telur perlakuan P0, P1, P2 dan P3 adalah sama dengan skor 1 . Skor warna kuning telur P0 $(2,39)$ lebih tinggi dibanding P1 $(1,39), P 2$ $(1,55)$ dan P3 $(1,11)$. Skor aroma P0 $(2,30)$ adalah paling rendah dibanding P1 $(2,38), \mathrm{P} 2(2,53)$ dan P3 $(2,41)$. Skor rasa P0 $(2,33)$ adalah paling rendah dibanding P1 $(2,52)$, P2 $(2,55)$ dan $\mathrm{P} 3(2,72)$. Skor tekstur P0 $(2,58)$ lebih rendah dibanding P1 $(2,61)$ dan P2 $(2,61)$, tetapi lebih tinggi dibanding P3 $(2,53)$. Skor kesukaan P0 $(3,53)$ adalah paling rendah dibanding P1 $(4,03)$, P2 $(3,85)$ dan P3 $(4,07)$.
\end{abstract}

Kata kunci : bumbu rendang, telur asin, uji organoleptik. 


\section{Pendahuluan}

Latar Belakang

Telur merupakan salah satu produk pangan hewani yang mudah rusak dan busuk, pada umumnya telur akan mengalami kerusakan setelah disimpan lebih dari dua minggu di ruang terbuka, baik kerusakan secara fisik, kimiawi maupun biologis yang disebabkan oleh mikroorganisme (Sudaryani, 1996). Oleh sebab itu diperlukan berbagai cara untuk mempertahankan telur dalam jangka waktu yang cukup lama diantaranya dengan menggunakan teknologi pengasinan. Telur asin merupakan salah satu bentuk pengawetan telur yang dapat ditemukan di beberapa Negara, misalnya Indonesia, Cina dan Taiwan. Keuntungan dari teknologi pengasinan ini disamping pengawetan adalah meningkatkan cita rasa.

Telur asin biasanya diawetkan dengan cara pemeraman sehingga dapat bertahan hingga \pm 3 minggu. Telur yang diawetkan dengan cara ini selain awet juga memiliki rasa yang khas. Fungsi garam pada pengawetan ini adalah untuk menembus pori-pori kulit telur bagian dalam, putih telur dan kuning telur sehingga bagian bagian tersebut menjadi asin dan mampu menghambat hidup bakteri dan mikroorganisme. Pengasinan telur umumnya dilakukan dengan dua cara, yaitu perendaman dalam larutan garam dan pemeraman dengan adonan campuran garam dan abu, serbuk batu bata atau tanah liat (Kastaman et al, 2005).

Berdasarkan penelitian Listyorini (2010), telur yang diasinkan dengan menggunakan serbuk batu bata dapat menghilangkan bau amis dan memperpanjang masa simpan telur, karena dengan pengasinan dapat menekan pertumbuhan mikroorganisme dalam telur sehingga menekan terjadinya pembusukan.

Suyasa (2002), menyatakan bahwa bumbu rendang memiliki aktivitas antimikroba terhadap flora mikroba yang terdapat pada ekstrak daging, santan serta campuran daging dan santan. Efek penghambatan bumbu rendang terhadap beberapa bakteri yang diujikan diduga karena adanya aktivitas antimikroba rempah-rempah dalam bumbu. Komponen antimikroba setelah dipanaskan akan terurai menjadi komponen-komponen yang lebih mudah berpenetrasi ke dalam sel mikroba, merusak dinding sel, sitoplasma dan mengkoagulasi protein sel mikroba sehingga menyebabkan kematian sel mikroba.

Rendang adalah masakan yang berasal dari suku minangkabau tetapi saat ini umum disajikan diseluruh Indonesia. Rendang merupakan salah satu makanan khas dari kebudayaan minangkabau yang disajikan pada saat-saat penting seperti upacara atau untuk menghormati tamu. Rendang dibuat dari daging sapi atau dapat juga dari daging ayam, kerbau dan bebek yang dimasak denga santan dan rempah-rempah selama beberapa jam sampai air habis dan daging menyerap bumbu rempah-rempah. Proses memasak berubah dari merebus menjadi menggoreng saat airnya menguap. Rempah-rempah yang digunakan yaitu jahe, kunyit, lengkuas, daun jeruk dan cabai (Anonim, 2012)

Tujuan Penelitian

Penelitian ini bertujuan untuk mengevaluasi penambahan level bumbu rendang yang berbeda pada pembuatan telur asin terhadap uji organoleptik.

Hipotesis

Penambahan rempah-rempah bumbu rendang pada pembuatan telur asin diduga dapat meningkatkan kesukaan masyarakat terhadap produk olahan telur asin dari segi rasa, warna, aroma, dan tekstur dari telur asin.

\section{Bahan dan Metode}

Materi yang digunakan dalam penelitian ini adalah telur asin yang dibuat dengan menambahkan rempah-rempah bumbu rendang. Telur yang digunakan dalam pembuatan telur asin adalah telur itik yang diperoleh langsung dari peternakan itik. Bahan-bahan yang digunakan :telur itik, garam dapur $(\mathrm{NaCl})$, abu gosok dan bumbu rendang. Alat-alat yang digunakan dalam pembuatan telur asin seperti baskom, ember, toples, dandang dan kompor.

Waktu dan Lokasi Penelitian

Penelitian telah dilaksanakan pada bulan Maret sampai April 2017 bertempat di Laboratorium Jurusan Peternakan Fakultas Pertanian Universitas Bengkulu.

Tahapan penelitian

1. Penyortiran telur 
Menyortir telur itik yang telah disiapkan dengan memisahkan telur yang kerabangnya pecah dengan telur yang masih dalam kondisi utuh.

2. Pembersihan telur

Telur yang akan diasin, dicuci bersih dari kotoran-kotoran yang menempel pada kerabang dengan cara mencuci dengan menggunakan air bersih, kemudian mengeringkan dengan menggunakan kain.

3. Pembuatan bumbu rendang

Pembuatan bumbu rendang yaitu menggiling bumbu yang sudah disiapkan (bawang merah, bawang putih, cabe merah, kunyit, ketumbar, jahe, kelapa kering) dicampur menjadi satu. Setelah semua bumbu halus, bumbu dimasak \pm 30 menit.

4. Pembuatan adonan

Mencampur bahan adonan seperti abu gosok, garam, air dan bumbu rendang yang telah dimasak menjadi satu dalam sebuah tempat dengan ukuran yang telah ditentukan.

5. Pembungkusan telur

Proses selanjutnya yaitu membalut telur yang telah dibersihkan dengan adonan.

\section{Pemeraman}

Memeram telur yang telah dibalut adonan selama 15 hari. Menurut Lesmayati et al, (2014) pemeraman 15 hari menghasilkan aroma dan warna telur asin yang disukai konsumen.

7. Pembersihan telur asin

Membersihkan telur yang telah diperam selama 15 hari dari balutan adonan, kemudian mencuci dengan menggunakan air bersih dan mengeringkan dengan menggunakan kain.

8. Pengambilan sampel

Mengambil sampel telur asin yang telah dibersihkan, dari masing-masing perlakuan dan ulangan untuk dijadikan sampel uji organoleptik.

9. Perebusan telur

Setelah itu mengambil beberapa butir telur asin yang telah dibersihkan untuk direbus selama \pm 15 menit untuk dilakukan uji organoleptik.

10. Uji organoleptik

Menguji organoleptik telur yang telah direbus dengan menggunakan 16 panelis tidak terlatih dengan beberapa parameter yang diujikan yaitu : rasa, warna, aroma dan tekstur dari telur asin.

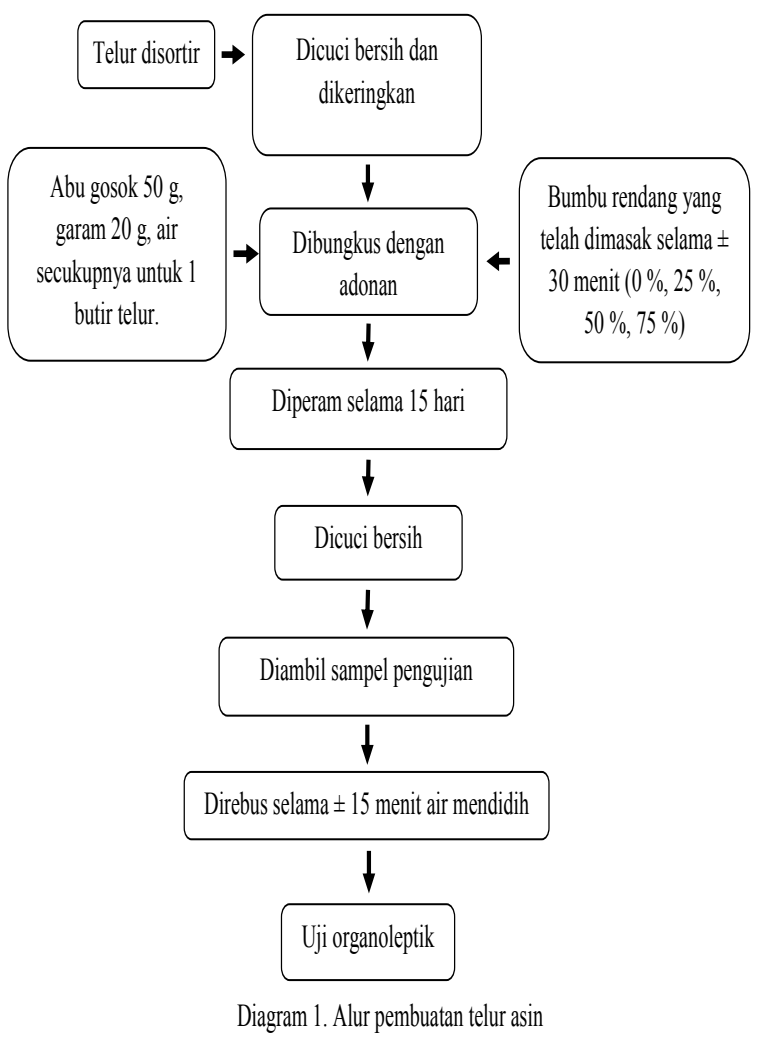

Rancangan Penelitian

Rancangan yang digunakan adalah RAL (rancangan acak lengkap), rancangan ini menggunakan 4 perlakuan dan 4 ulangan, setiap ulangan menggunakan 5 butir telur, jadi total telur 80 butir dengan faktor yang diukur adalah level bumbu rendang. Level bumbu rendang yang digunakan berbeda persentase terhadap abu gosok, garam dan air dengan ukuran yang sama. Level bumbu rendang yang digunakan yaitu :

$\mathrm{PO}=$ Adonan $+0 \%$ bumbu rendang (kontrol)

$\mathrm{P} 1=$ Adonan $+25 \%$ bumbu rendang

$\mathrm{P} 2=$ Adonan $+50 \%$ bumbu rendang

$\mathrm{P} 3=$ Adonan $+75 \%$ bumbu rendang

Variabel Pengamatan

- Uji organoleptik

Tingkat kesukaan masyarakat dilakukan dengan uji organoleptik menggunakan 16 panelis tidak terlatih. Parameter yang diujikan : rasa, warna, aroma dan tekstur dari telur asin. Skor yang digunakan untuk uji organoleptik disajikan pada Tabel 1.

Tabel 1. Skor parameter yang diukur pada uji organoleptic 


\begin{tabular}{llllll}
\hline $\begin{array}{l}\text { Skor } \\
\text { Telurna putih } \\
\text { telur }\end{array}$ & $\begin{array}{l}\text { Warna kunig } \\
\text { telur }\end{array}$ & Bau & Rasa & Tekstur \\
\hline 1 & Putih & Kuning & Sangat amis & $\begin{array}{l}\text { Sangat tidak } \\
\text { enak }\end{array}$ & $\begin{array}{l}\text { Sangat } \\
\text { lembek }\end{array}$ \\
& & & & Tidak enak & Tidak \\
2 & Putih kecoklatan & Kuning & Amis & & lembek \\
& & kecoklatan & & & Padat \\
3 & Coklat & Coklat & Tidak amis & Enak & Sangat \\
4 & Coklat gelap & Coklat gelap & Sangat tidak & Sangat enak & Sadat \\
\hline
\end{tabular}

Sumber : Larmond (1970).

- Uji tingkat kesukaan konsumen

Tingkat kesukaan konsumen dinilai dengan menggunakan skala hedonik (tingkat kesukaan) dengan skor 1-7, dimana skor 1 menggambarkan nilai sangat tidak suka dan skor 7 menggambarkan nilai sangat suka. Panelis diminta menilai produk pada rentang nilai skor 1-7 seperti disajikan pada Tabel 2 .

Tabel 2. Skoring uji hedonic

\begin{tabular}{ll}
\hline Skor & Keterangan \\
\hline 1 & Sangat tidak suka \\
2 & Tidak suka \\
3 & Agak tidak suka \\
4 & Netral \\
5 & Agak suka \\
6 & Suka \\
7 & Sangat suka \\
\hline Sumber: Soekarto (1985). &
\end{tabular}

Analisis Data

Data yang diperoleh dari hasil uji organoleptik berupa, warna, aroma, rasa, tekstur dan kesukaan ditabulasi, selanjutnya dianalisis dan dibahas secara deskriptif terhadap semua variabel yang diamati.

\section{Hasil dan Pembahasan Warna Putih Telur}

Pengaruh penambahan bumbu rendang dalam pemeraman telur asin terhadap uji organoleptik warna putih telur dapat dilihat pada Tabel 3.

Hasil penelitian menunjukkan skor warna putih telur asin yang diperam dengan adonan yang mengandung bumbu rendang ( $P 1, P 2$ dan P3) sama dengan yang tidak mengandung bumbu rendang (PO). Skor warna putih telur dari masing-masing perlakuan adalah 1,00 . Hal ini menunjukkan bahwa penambahan bumbu rendang pada adonan pemeraman telur asin tidak mempengaruhi warna putih telur.
Tabel 3. Rata-rata skor uji organoleptik warna putih telur asin setiap perlakuan

\begin{tabular}{|c|c|c|c|c|c|c|}
\hline \multirow{2}{*}{ Perlakuan } & \multicolumn{4}{|c|}{ Ulangan } & \multirow{2}{*}{$\begin{array}{c}\text { Rata-rata } \pm \\
\text { SD }\end{array}$} & \multirow{2}{*}{$\begin{array}{c}\text { Peningkatan } \\
(\%)\end{array}$} \\
\hline & 1 & 2 & 3 & 4 & & \\
\hline P0 & 1 & 1 & 1 & 1 & $1,00 \pm 0,00$ & - \\
\hline P1 & 1 & 1 & 1 & 1 & $1,00 \pm 0,00$ & - \\
\hline P2 & 1 & 1 & 1 & 1 & $1,00 \pm 0,00$ & - \\
\hline P3 & 1 & 1 & 1 & 1 & $1,00 \pm 0,00$ & - \\
\hline
\end{tabular}

Keterangan: $\mathrm{P} 0$ = Sebagai kontrol, telur asin yang diperam dengan adonan abu gosok dan garam tanpa penambahan bumbu rendang.

P1 = Telur asin yang diperam dengan adonan abu gosok dan garam dengan penambahan $25 \%$ bumbu rendang.

P2 = Telur asin yang diperam dengan adonan abu gosok dan garam dengan penambahan $50 \%$ bumbu rendang.

P3 = Telur asin yang diperam dengan adonan abu gosok dan garam dengan penambahan $75 \%$ bumbu rendang.

Warna menjadi atribut kualitas yang paling penting, walaupun suatu produk pangan bernilai gizi tinggi, rasa enak dan tekstur baik, apabila warna yang ditampilkan kurang menarik akan menyebabkan produk pangan kurang diminati oleh konsumen. Pengujian dengan indra penglihatan masih sangat menentukan dalam pengujian sensori warna pada produk pangan (Setyaningsih, 2008). Warna yang disukai pada telur asin yaitu putih pada bagian putih telur dan kuning kemerahan pada bagian kuning telurnya (Putri, 2011).

\section{Warna kuning telur}

Pengaruh penambahan bumbu rendang dalam pemeraman telur asin terhadap uji organoleptik warna kuning telur dapat dilihat pada Tabel 4.

Hasil penelitian menunjukkan bahwa skor warna kuning telur asin yang diperam dengan adonan yang mengandung bumbu rendang (P1, P2 dan P3) adalah lebih rendah dibandingkan dengan adonan yang tidak mengandung bumbu rendang (PO). Skor warna kuning telur asin tersebut adalah P0 (2,39), P1 $(1,39)$, P2 $(1,55)$ dan P3 $(1,11)$. Hal ini menunjukkan bahwa penggunaan bumbu rendang pada adonan pemeraman telur asin berpengaruh negatif pada warna kuning telur. Diduga penurunan skor pada warna kuning telur disetiap perlakuan karena banyaknya minyak yang dihasilkan dari bumbu rendang yang dimasak selama \pm 30 menit. 
Tabel 4. Rata-rata skor uji organoleptik warna kuning telur asin setiap perlakuan

\begin{tabular}{|c|c|c|c|c|c|c|}
\hline \multirow{2}{*}{ Perlakuan } & \multicolumn{4}{|c|}{ Ulangan } & \multirow{2}{*}{$\begin{array}{l}\text { Rata-rata } \pm \\
\text { SD }\end{array}$} & \multirow{2}{*}{$\begin{array}{c}\text { Peningkatan } \\
(\%)\end{array}$} \\
\hline & 1 & 2 & 3 & 4 & & \\
\hline $\mathrm{P} 0$ & 2,56 & 2,19 & 2,31 & 2,50 & $2,39 \pm 0,17$ & - \\
\hline P1 & 1,38 & 1,69 & 1,19 & 1,31 & $1,39 \pm 0,21$ & $-41,84$ \\
\hline P2 & 1,69 & 1,44 & 1,75 & 1,31 & $1,55 \pm 0,21$ & $-35,15$ \\
\hline P3 & 1,06 & 1,25 & 1,06 & 1,06 & $1,11 \pm 0,10$ & $-53,56$ \\
\hline
\end{tabular}

Penelitian Lesmayati et al. (2014), menunjukkan bahwa rata-rata tingkat kesukaan terhadap warna kuning telur asin dengan criteria agak suka sampai suka, dimana dari perhitungan sidik ragam diperoleh hasil lama pemeraman tidak berpengaruh terhadap kesukaan konsumen terhadap warna kuning telur asin.

\section{Aroma}

Pengaruh penambahan bumbu rendang dalam pemeraman telur asin terhadap uji organoleptik aroma telur dapat dilihat pada Tabel 5.

Tabel 5. Rata-rata skor uji organoleptik aroma telur asin setiap perlakuan

\begin{tabular}{ccccccc}
\hline \multirow{2}{*}{ Perlakuan } & \multicolumn{4}{c}{ Ulangan } & Rata-rata \pm SD & $\begin{array}{c}\text { Peningkatan } \\
(\%)\end{array}$ \\
\cline { 2 - 5 } & $\mathbf{1}$ & $\mathbf{2}$ & $\mathbf{3}$ & $\mathbf{4}$ & & (\%, \\
\hline P0 & 2,44 & 2,19 & 2,25 & 2,31 & $2,30 \pm 0,11$ & - \\
P1 & 2,38 & 2,38 & 2,69 & 2,06 & $2,38 \pm 0,26$ & 3,48 \\
P2 & 2,56 & 2,50 & 2,56 & 2,50 & $2,53 \pm 0,03$ & 10,00 \\
P3 & 2,44 & 2,38 & 2,38 & 2,44 & $2,41 \pm 0,03$ & 4,78 \\
\hline
\end{tabular}

Hasil penelitian menunjukkan bahwa skor aroma telur asin yang diperam dengan adonan yang mengandung bumbu rendang (P1, P2 dan P3) adalah lebih tinggi dibandingkan dengan adonan yang tidak mengandung bumbu rendang (P0). Skor aroma telur asin tersebut adalah P0 $(2,30), \mathrm{P} 1(2,38)$, P2 $(2,53)$ dan P3 $(2,41)$. Hal ini menunjukkan bahwa penggunaan bumbu rendang pada adonan pemeraman telur asin dapat menurunkan aroma amis telur asin.

Kartika et al. (1988) dan Setyaningsih (2008), menyatakan bahwa aroma adalah bau yang dapat diamati dengan indra pembau. Pengujian bau atau aroma adalah suatu pengujian yang penting karena dapat memberikan hasil penilaian terhadap daya terima produk.Aroma dapat digunakan sebagai indikator terjadinya kerusakan pada produk pangan. Telur asin yang sudah tidak layak dikonsumsi akan berbau sangat menyengat/busuk. Aroma memiliki fungsi yang penting dalam produk pangan, karena sebelum mengkonsumsi biasanya terlebih dahulu aroma makanan tercium oleh indra hidung, apabila aroma pada produk terlalu menyengat atau terkesan hambar akan membuat konsumen tidak tertarik untuk mengkonsumsinya.

\section{Rasa}

Rasa merupakan salah satu faktor penting dalam produk pangan. Rasa telur asin umumnya terasa asin, sesuai dengan tingkat pemberian garam dalam pembuatan telur asin dan juga lama pemeraman. Dari hasil yang didapat Pengaruh penambahan bumbu rendang terhadap uji organoleptik rasa telur asin dapat dilihat pada Tabel 6.

Tabel 6. Rata-rata skor uji organoleptik rasa telur asin setiap perlakuan

\begin{tabular}{ccccccc}
\hline \multirow{2}{*}{ Perlakuan } & \multicolumn{4}{c}{ Ulangan } & Rata-rata \pm SD & $\begin{array}{c}\text { Peningkatan } \\
(\%)\end{array}$ \\
\cline { 2 - 5 } & $\mathbf{1}$ & $\mathbf{2}$ & $\mathbf{3}$ & $\mathbf{4}$ & & - \\
\hline P0 & 2,56 & 2,13 & 2,25 & 2,38 & $2,33 \pm 0,18$ & - \\
P1 & 2,31 & 2,44 & 2,88 & 2,44 & $2,52 \pm 0,25$ & 8,15 \\
P2 & 2,44 & 2,56 & 2,63 & 2,56 & $2,55 \pm 0,08$ & 9,44 \\
P3 & 2,75 & 2,69 & 2,75 & 2,69 & $2,72 \pm 0,03$ & 1,74 \\
\hline
\end{tabular}

Hasil penelitian menunjukkan bahwa skor rasa telur asin yang diperam dengan adonan yang mengandung bumbu rendang (P1, P2 dan P3) adalah lebih tinggi dibandingkan dengan yang tidak mengandung bumbu rendang (PO). Skor rasa telur asin tersebut adalah P0 $(2,33)$, P1 $(2,52)$, P2 $(2,55)$ dan P3 $(2,72)$. Hal ini menunjukkan bahwa penambahan bumbu rendang pada adonan pemeraman telur asin dapat meningkatkan kesukaan rasa telur asin. Diduga adanya hubungan antara pemberian garam dengan level bumbu rendang yang semakin tinggi akan mengurangi rasa asin pada telur.

\section{Tekstur}

Pengaruh penambahan bumbu rendang dalam pembuatan telur asin terhadap uji 
organoleptik tekstur telur dapat dilihat pada Tabel 7.

Tabel 7. Rata-rata skor uji organoleptik tekstur telur asin setiap perlakuan

\begin{tabular}{|c|c|c|c|c|c|c|}
\hline \multirow{2}{*}{ Perlakuan } & \multicolumn{4}{|c|}{ Ulangan } & \multirow{2}{*}{ Rata-rata \pm SD } & \multirow{2}{*}{$\begin{array}{c}\text { Peningkatan } \\
(\%)\end{array}$} \\
\hline & 1 & 2 & 3 & 4 & & \\
\hline P0 & 2,56 & 3,00 & 2,38 & 2,38 & $2,58 \pm 0,29$ & - \\
\hline P1 & 2,38 & 2,69 & 2,81 & 2,56 & $2,61 \pm 0,18$ & 1,16 \\
\hline P2 & 2,75 & 2,69 & 2,56 & 2,44 & $2,61 \pm 0,14$ & 1,16 \\
\hline P3 & 2,44 & 2,63 & 2,56 & 2,50 & $2,53 \pm 0,08$ & $-1,94$ \\
\hline
\end{tabular}

Hasil penelitian menunjukkan bahwa skor tekstur telur asin yang diperam dengan adonan yang mengandung bumbu rendang ( $\mathrm{P} 1$ dan $\mathrm{P} 2$ ) lebih tinggi dibandingkan dengan $\mathrm{P} 3$ dan $\mathrm{PO}$ yang tidak mengandung bumbu rendang. Skor tekstur telur asin tersebut adalah P0 $(2,58), \mathrm{P} 1$ $(2,61)$, P2 $(2,61)$ dan P3 $(2,53)$. Hal ini menunjukkan bahwa P1 dan P2 dapat meningkatkan tekstur, sedangkan P3 tidak dapat meningkatkan tekstur telur.

\section{Kesukaan}

Pengaruh penambahan bumbu rendang terhadap uji organoleptik kesukaan telur asin rasa rendang dapat dilihat pada Tabel 8 .

Tabel 8. Rata-rata skor uji organoleptik kesukaan telur asin setiap perlakuan

\begin{tabular}{ccccccc}
\hline \multirow{2}{*}{ Perlakuan } & \multicolumn{4}{c}{ Ulangan } & Rata-rata \pm SD & $\begin{array}{c}\text { Peningkatan } \\
(\%)\end{array}$ \\
\cline { 2 - 5 } & $\mathbf{1}$ & $\mathbf{2}$ & $\mathbf{3}$ & $\mathbf{4}$ & & - \\
\hline P0 & 4,19 & 2,81 & 3,38 & 3,75 & $3,53 \pm 0,58$ & - \\
P1 & 3,88 & 3,56 & 4,94 & 3,75 & $4,03 \pm 0,62$ & 14,16 \\
P2 & 3,75 & 4,19 & 3,94 & 3,50 & $3,85 \pm 0,29$ & 9,07 \\
P3 & 4,38 & 4,00 & 4,00 & 3,88 & $4,07 \pm 0,22$ & 15,30 \\
\hline
\end{tabular}

\section{Kesimpulan}

Berdasarkan hasil pembahasan diatas dapat disimpulkan bahwa pembuatan telur asin dengan penambahan bumbu rendang tidak mempengaruhi warna putih telur asin, namun menurunkan warna kuning pada telur asin dan dapat menurunkan aroma amis pada telur asin sehingga meningkatkan rasa telur asin. Skor tekstur PO $(2,58)$ lebih rendah dibanding P1 $(2,61)$ dan P2 $(2,61)$, tetapi lebih tinggi dibanding $\mathrm{P} 3(2,53)$.

\section{Daftar Pustaka}

Abubakar dan M. Ilyas. 2005. Mutu Susu Karamel Asal Susu Pecah selama Penyimpanan. Seminar Nasional Teknologi Peternakan dan Veteriner 2005.

Anonim. 2010. Beberapa manfaat yang terkandung dalam bawang merah. http://paijah.com/beberapa-manfaatyang-terkandung-dalam-bawangmerah.html. diakses 28 september 2016.

Anonim. 2012. Pengertian Bumbu dan Rempah. Diperoleh 28 Desember 2016, dari jelajahiptek.blogspot.com/pengertiantentang-bumbu-dan-rempah.

Apendi, K. Widayaka, dan J. Sumarmono. 2013. Evaluasi Kadar Asam Lemak Bebas dan Sifat Organoleptik pada Telur Asin Asap dengan Lama Pengasapan yang Berbeda. Jurnal IImiah Peternakan 1 (1): 142-150.

Budiyanto, M. A. K. 2002. Dasar-dasar Ilmu Gizi. Malang : UMM press.

Hidayat, A. 2007. Pengaruh Perbedaan Cara dan Lama Pemasakan Telur Asin terhadap Sifat Organoleptik. Skripsi. Fakultas Peternakan Universitas Jenderal Soedirman. Purwokerto.

Kartika., Bambang., P. Hastuti dan W. Suprapto. 1988. Pedoman Uji Indrawi Bahan Pangan. UGM.Yogyakarta.

Kastaman, R., Sudaryanto dan B. H. Nopianto. 2005. Kajian Proses Pengasinan Telur Metode Reverse Osmosis pada Berbagai Perendaman. Jurusan Teknik dan Manajemen Industri Pertanian. 19 (1): 3039.

Larmond, E. 1970.Methods for Sensory Evaluation of Food. Food Research Institute. Central Experiment Farm. Ottawa.

Lesmayati, S., Rohaeni, E. S., dan Barnuwati 2014.Pengaruh Lama Pemeraman Telur Asin. Pengkajian Teknologi Pertanian. Banjarbaru, Kalimantan Selatan.

Listyorini, R. 2010. Perbandingan Kadar Protein dan Sifat Organoleptik pada Telur Asin Hasil Perendaman Serbuk Batu Bata Merah dengan Telur Bebek Tanpa Pengasinan. 
Skripsi S-1 Prodi Biologi. FKIP Biologi Universitas Muhammadyah Surakarta.

Muchtadi, T. R., dan Sugiyono. 1992. Ilmu Pengetahuan Bahan Pangan. Petunjuk Laboratorium. Departemen Pendidikan dan Kebudayaan. Direktorat Jendral Pendidikan Tinggi. Pusat Antar Universitas Pangan dan Gizi. IPB, Bogor

Murtidjo, B. A. 1990. Pengelolaan Itik. Kanisius.Yogyakarta.

Nurhidayat, Y., J. Sumarno, dan S. Wasito. 2013. Kadar Air, Kemasiran dan Tekstur Telur Asin Ayam Niaga yang Dimasak dengan Cara yang Berbeda. Jurnal IImiah Peternakan. 1 (3): 813-820.

Pfanner, E. 2007. A Place Where Cholesterol is Welcome; in billboard. The New York Times Edition in Suddeutsche Zeitung.

Purwaningsih, E. 2007. Bawang putih. Ganeca : Jakarta.

Putera, S. E. 2016. Tingkat Kesukaan Konsumen dan Kualitas Kimia Telur Asin dengan Metode Injeksi. Skripsi S-1 Prodi Peternakan. Fakultas Pertanian Universitas Bengkulu.

Putri, I. S. I. 2011 Pengaruh Penambahan Ekstrak Jahe (Zingiber officenale roscoe) terhadap Aktivitas Antioksidan, Total Fenol dan Karakteristik Sensori pada Telur Asin. Skripsi. Fakultas Teknologi Hasil Pertanian Universitas Sebelas Maret Surakarta. Surakarta.

Rasyaf, M. 2005. Beternak Ayam Petelur. Penebar Swadaya. Jakarta.

Setyaningsih. D, A. 2008. Analisis Sensori Untuk Agroindustri. Bogor.

Simanjuntak. O. E., S. Wasito, dan K. Widayaka. 2013. Pengaruh Lama Pengasapan Telur
Asin dengan Menggunakan Serabut Kelapa terhadap Kadar Air dan Jumlah Bakteri Telur Asin Asap. Jurnal IImiah Indonesia. 1 (1): 195-200.

Slamet, Y. 2005. Formulasi Minuman Fungsional Untuk Kelompok Gizi Khusus dari Kecambah Kacang Hijau (Phaseolus radiatus, Linn) dan Sari Jahe (Zingiber officinale Roscoe). Skripsi. Departemen Ilmu dan Teknologi Pangan. Fakultas Teknologi Pertanian. IPB. Bogor

Soekarto, S. T. 1985. Penilaian Organoleptik Untuk Industri Pangan dan Hasil Pertanian. Bharata Karya Aksara. Jakarta.

Sudaryani, T. 1996. Telur dan Hasil Olahannya. Penebar Swadaya. Jakarta.

Sudaryani, T. 2003. Kualitas Telur. Penebar Swadaya. Jakarta.Suprapti, M. L. 2002. Pengawetan Telur. Kanisius, Yogyakarta.

Suyasa, I. N. 2002. Penambahan Asam Asetat dan Asam Laktat serta Pengaruhnya terhadap Kualitas Daging Sapi. Tesis. Program Pasca sarjana. Bogor. Institut Pertanian Bogor.

Sutejo, M.M. 1990. Pengembangan Kultur Tanaman Berkhasiat Obat. Rineke Cipta. Jakarta.

Tri, R. M. G. 2009. Kandungan Beta Karoten dan Nilai Gizi Telur Asin dari Itik yang Mendapat Pakan Limbah Udang. Skripsi. Bogor : Institut Pertanian Bogor.

Widjaja, K. 2003. Peluang Bisnis Itik. Penebar Swadaya. Jakarta.

Winarno, F. G. 1997. Kimia Pangan dan Gizi. Jakarta : PT. Gramedia Pustaka Utama.

Wibowo, S. 1995. Budidaya Bawang. Penebar Swadaya: Jakarta 